\title{
The statesman of education, science and technology
}

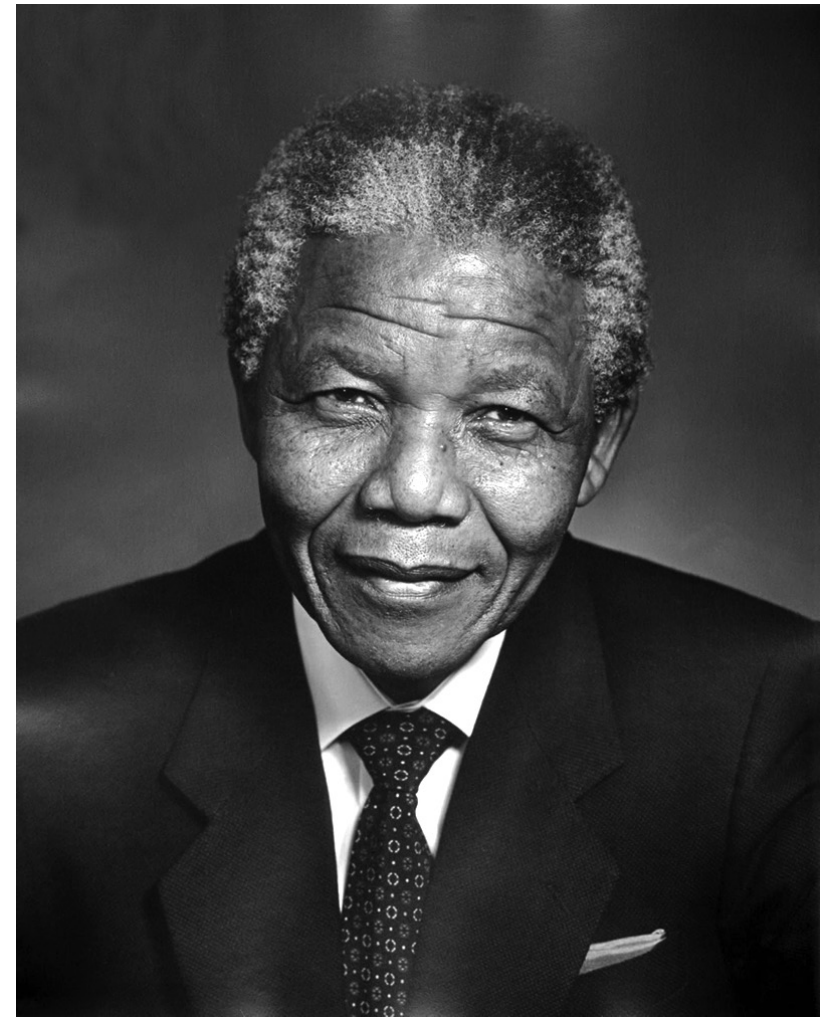

Photo: Festival Karsh (CC)

(http://creativecommons.org/licenses/by-nc-nd/2.0/)

Nelson Mandela, 1990

What has become of our rationality, our ability to think? We have used our reason to make great advances in science and technology, though often using those for warfare and plunder. We have placed people on the moon and in space; we have split the atom and transplanted organs; we are cloning life and manipulating nature. Yet we have failed to sit down as rational beings and eliminate conflict, war and consequent suffering of innocent millions, mostly women, children and the aged.

Nelson Mandela: Address on receiving the International Gandhi Peace Prize, 2000

Almost every South African who works in the fields of education, science or technology (EST) knows the famous Nelson Mandela statement that 'Education is the great engine of personal development'. But the words that the late president included in his acceptance speech on receiving the International Gandhi Peace Prize in 2000 take that idea into a much wider realm. Education is, of course, the basis for personal growth; yet, when coupled with its application in the realms of the broad world of all the sciences and of technology, it becomes the key to social and economic growth and justice. The South African Journal of Science pays tribute, here, to a statesman and leader who recognised that relationship and who strove, through his insights and leadership, to change the way in which all three fields could and would operate in a new democracy faced with vast challenges of social and economic justice.

Nelson Rolihlohlo Mandela's own words on education and science are enlightening. About his first experience in a 'proper hospital' after injuring his heel while on Robben Island, aggravating an earlier injury, he wrote2:
I found the trip [to the hospital] instructive ... because in that hospital I sensed a thawing in the relationship between black and white. The doctor and nurses had treated me in a natural way as though they had been dealing with blacks on a basis of equality all their lives. This was something new to me, and an encouraging sign. It reaffirmed my long-held belief that education is the enemy of prejudice. These were men and women of science, and science had no room for racism.

In the New Scientist of 06 December 2013, Calestous Juma, Professor in the Kennedy School of Government at Harvard, points out?

\begin{abstract}
For much of the world Nelson Mandela was the icon of the age of modern liberation that started with Mahatma Gandhi and reached its height with South Africa's first democratic elections in 1994. What is less well known is that the struggle for political freedom was closely associated with the desire to develop scientific and technological capacity.
\end{abstract}

During the years of apartheid - and before - educational opportunities for Black South Africans were severely limited. With the exception of missionary schools (and the University of Fort Hare, which grew out of a mission school) and, later, ethnically based universities and the University of Natal Medical School, opportunities for education at all levels were limited to very small numbers for anyone who was not White.

Transformation and national development had, as a consequence, to include major reformation in EST as a necessity - not just for 'the things in themselves', but in order to provide the knowledge and the applications - the broader engines of development - that would help to drive economic growth and the many changes (still) needed. As Cloete et al. ${ }^{4}$ explain:

[...T] There is increasing evidence that high levels of education in general, and of higher education in particular, are essential for the design and productive use of new technologies, while they also provide the foundations for a nation's innovative capacity, and contribute more than any other social institution to the development of civil society.

As President of South Africa, Nelson Mandela clearly grasped these relationships - both those between education and economic development and those among science, technology and the general development of society. So it is not surprising that Simon Connell, a member of the

HOW TO CITE: Butler-Adam J. The statesman of education, science and technology. S Afr J Sci. 2014;110(1/2), Art. \#a0052, 2 pages. http://dx.doi. org/10.1590/sajs.2014/a0052

(c) 2014. The Authors. Published under a Creative Commons Attribution Licence. 
Academy of Science of South Africa, and Professor of Physics in the University of Johannesburg, wrote ${ }^{5}$ :

Apart from creating a general political climate favourable to research, Mandela was known to intervene directly when science became politicised. An example was the contentious politics surrounding health issues in South Africa. He appealed, 'In the face of the grave threat posed by HIVIAIDS, we have to rise above our differences and combine our efforts to save our people. History will judge us harshly if we fail to do so now, and right now.'

Mr Mandela did not simply offer lip service to the role of EST but made it possible for the needed changes to happen and, when necessary, intervened in the contestation between science and politics on the side of science.

His commitment is also evident in the number of educational and research organisations to which he agreed to give his name - and, in some cases, his personal support and encouragement. Motivated by his insightfulness, Mandela lent his name to the creation of a new generation of African Institutes of Science and Technology. Two have already been established - in Tanzania and Nigeria - and a third is planned in Burkina Faso. His name is also that of a university (the Nelson Mandela Metropolitan University), a medical school (the Nelson R Mandela School of Medicine at the University of KwaZulu-Natal) and a pupil support centre in Uitenhage (the Nelson Mandela Bay Science and Technology Centre). Not to be overlooked is Mandela's patronage of the Academy itself; at the Academy's launch in 1996, Mandela made the observation, core to his view of EST, that the formation of the Academy 'is not an isolated act but part of the building of a new society which freedom has made possible'6.

In the same speech, Mandela went on to say

\begin{abstract}
South Africa's need for rapid expansion of its scientific and technological skills is immense. It is inhibited by the disastrous restriction which apartheid imposed on the level of scientific and technological education: and by an image of science tarnished in the eyes of the majority by associations with the past. On your shoulders rest the challenge of giving science a face that inspires our youth to seek out science, engineering and technology.
\end{abstract}

We would be neglectful were we to overlook the challenging problems that still beset the primary and secondary education subsystems in South Africa. While not exonerating universities, the Council on Higher Education's report $A$ proposal for undergraduate curriculum reform in South Africa makes it clear that 'it is widely accepted that student preparation [for higher education] is the dominant cause of the poor performance patterns in higher education' and 'that if higher education is to rely on improvement in schooling to deal with the systemic faults affecting it, there needs to be a rigorous assessment of the prospects of sufficient improvement being achieved within that sector.' This is an area in which there is still a long, long 'walk to success' to be completed.

Setting aside the current conditions of the primary and secondary subsystems, which require a return to the late president's understanding of the importance of science over politics in dire situations of need, his contributions to EST as key to South Africa's success have been monumental. His fundamental understanding that education and the sciences are the foundations of a non-racial society, his commitment to promoting this position (directly when necessary) and his insights into the relationships between EST and both economic growth and social justice as the basis of a successful democracy are the legacy he has left us.

Perhaps it is fitting then to end this tribute to a remarkable human being and champion, a true statesman of EST, with the words of another member of the Academy, Professor Salim Abdool Karim, President of the South African Medical Research Council: 'We will humbly try to continue following in [Nelson Mandela's] footsteps in the enduring quest to make our world a better place for all' ${ }^{1}$.

\section{References}

1. Department of Basic Education. Nelson Mandela quotes [document on the Internet]. c2014 [cited 2014 Jan 10]. Available from: http://www.education. gov.za/LinkClick. aspx?fileticket $=8 \mathrm{~d} 6 \mathrm{c}$ Phef\%2FL8\%3D\&tabid $=656 \& \mathrm{~m}$ id $=1849$

2. Mandela N. Long walk to freedom. Boston: Back Bay Books; 1995.

3. Juna C. Mandela's unsung legacy of science in Africa [Opinion]. New Sci [serial on the Internet]. 2013 Dec 06 [cited 2014 Jan 10]. Available from: http://www.newscientist.com/article/dn24712-mandelas-unsung-legacy-ofscience-in-africa.html\#.UtjJ1hCSwrX

4. Cloete N, Bailey T, Pillay P, Bunting I, Maassen P. Universities and economic development in Africa. Cape Town: Centre for Higher Education Transformation; 2011.

5. Connell S. What Mandela meant for science in South Africa [homepage on the Internet]. c2013 [cited 2014 Jan 10]. Available from: http://www.uj.ac. za/EN/Newsroom/News/Pages/What-Mandela-meant-for-Science-in-SouthAfrica aspx.

6. Mandela N. Address by President Nelson Mandela on the inauguration of the Academy of Science of South Africa [speech on the Internet]. c1996 [cited 2014 Jan 10]. Available from: http://www.mandela.gov.za/mandela speeches/1996/960322_science.htm

7. Makoni M, Grange H. Mandela 'aided scientific renaissance in South Africa' SciDev.Net [online]. 2013 Dec 19 [cited 2014 Jan 10]. Available from: http://www.scidev.net/global/education/news/mandela-aided-scientificrenaissance-in-south-africa-1.html 